general's badge or epaulet with the red cross, after the Ninth International Medical Congress, as well as some recognition of your own untiring service as Secretary General.

I think if you will suggest this thought in some suitable way it will not be too early to call attention to it now, and you will be surprised what a universally responsive chord it will strike in the hearts of the profession. Yours, D. L.

\section{Reuben D. Mussey.}

New Castle, Colo, June 8, 1896.

To the Editor:-During my first course of lectures at the Ohio Medical College, 1848-9, R. D. Mussey was Professor of Surgery. He was always kind to his students and patients, though sometimes decidedly brusque with those who had by improprieties brought themselves to grief. As an illustration, a man was placed on the table at the Commercial Hospital with a bubo in either groin. The Professor said: "Young gentlemen, we open these abscesses with a number of small punctures," suiting his action to the word. The patient's hand went involuntarily to the wound with the cry of " $\mathrm{Oh}$ God! oh God!" The Professor bluntly said: "Turn over, sir; 'the way of the transgressor is hard; they that sow to the wind must reap the whirlwind.' We open this, you see, in the same way."

Age had made his hand tremulous, and it trembled until the knife touched the desired spot, when it was as steady as in youth.

His lectures were always practical, but extremely terse, never adorned by a single flower.

In the summer of 1849 I went East with Dr. Lyman Beecher, father of Henry Ward, wife and daughter and Dr. Mussey. We crossed Lake Erie on the 4th of July, and at the instance of Dr. Mussey, the passengers invited Dr. Beecher to give us an oration. At Buffalo we parted company with Dr. Mussey, meeting him again at Saratoga and Hanover, N. H., Dr. Beecher and family and myself going to Niagara, Lundy's Lane, and across Ontario to Oswego and so to Saratoga, where we again met Dr. Mussey. Parting company here with these venerable and noble people I went to Caldwell and crossed Lakes George and Champlain to Burlington, and thence by stage via Montpelier to Dartmouth College, where I again met Dr. Mussey and his son, who was a student at Dartmouth. Turning his boy about, he said: "Feel of him ; he has never tasted meat."

I suppose all men have their hobbies, and some physicians ride them wildly. Professor Mussey's was diet, well-nigh absolute. After some of his operations he kept the patient for twenty days upon water and three small crackers a day. He was personally very abstemious and for many years a strict vegetarian. He was honest, earnest, a hard student and always a Christian gentleman. In his daily walk and professional life he was a fit exemplar to us all. $\quad$ W. L. Scherck, M.D.

\section{The Second Pan-American Medical Congress.}

Chicago, June 5, 1896.

To the Editor:-To the dignified letter in the May 30 number of the JourNaL, protesting against the unjust attack on the Mexican people and medical profession, allow me to add my own experiences in support of Dr. Cerna, in the hope that the medical profession in this country may not become prejudiced against our southern neighbors. It would be a pity if any word of hostility to the Mexicans should be the means of reducing the number of those who expect to attend the next Pan-American Medical Congress, because this will undoubtedly be the test meeting, and if it is poorly supported, interest will cease and our relationship with the rest of America will return to the apathy of former years.

I A bronze medal was struck, commemorative of this Congress and its chief officers, in 1887 .
I have practiced medicine among the Mexicans on terms of greatest intimacy, mèting all classes and finding all degrees of education. I know that Anglo-Saxons are not Mexicans nor Mexicans Anglo-Saxons, but this is a vital reason why it is unjust to study them from one standpoint only. I grant that the percentage of illiteracy is bigh and superstition consequently more evident, but I failed to find impenetrable stupidity among them, while I did find that the doctor is held in much higher respect than he is in Texas. Next to the priest comes the doctor, and his patient follows the doctor's directions with a strictness that seldom marks the attitude of the patient in this country. Doctors are not nearly so abundant there, and their journeys are often of enormous distances ; yet I never found anything but courtesy and hospitality in making my visits, and I was never refused payment for my labor, aithough my fees were sometimes reduced at the pleadings of the patient.

The National School of Medicine, a part of the University of the City of Mexico, grants degrees entitling the holder to practice throughout the Republic, while a few local schools like that at Monterey can grant this right within the one state only. The result is that the graduate of the National School is a wellposted man, fit to be admitted, as equal, to any medical association in the world; but while the graduate of the local school may be uninstructed in the technique of some of our modern methods, he is always an educated man, able to write his own language and his prescriptions correctly, and fitted to take an honorable place in the society to which his ambition calls him. The Mexican doctor is never ignorant; he may sometimes fail to practice the principles of antisepsis and asepsis, and he may often purge and puke rather briskly in fevers and inflammations, but not every surgeon outside of Mexico avails himself of the principles of his art, nor does every physician in our country abstain from the use of calomel when his diagnosis is doubtful. Above all this, the Mexican physician preserves his dignity, and respects himself and his profession, so that his influence in the community is far greater than is ours at home.

I need say nothing of the morals of the Mexican people. I found them about the same as one finds morals in England, Germany or Spain. But the resident of San Antonio or Chicago had better purify his own social atmosphere before condeming that of his neighbor.

I have purposely generalized my note, but did not space prevent, I could give many an illustration of the courtesy of that people, and of their honor for the man of education, while instances of the very traits criticized in the Mexicans can be found within our borders.

Any one who attends the meeting in the City of Mexico next November will meet with unbounded hospitality, and will return with such broadened knowledge that he will earnestly desire the perpetuity of the Pan-American Medical Congress. Very respectfully yours,

Albert B. Hale, M.D.

\section{The Colorado Ice Decision Not Final.}

Bureau of Health, Denver, Colo., June 10, 1896. To the Editor:-I have noted with some interest the editorial excerpt published in last week's issue of a recent decision of the Colorado Court of Appeals in regard to the limitations of the power of a health commissioner to condemn ice.

Inasmuch as the opinion as rendered is quite misleading and has deliberately ignored, or in some instances contradicts the record as certified in the lower court, and also because the decision as rendered by the court of appeals is not final, the case being now pending in the supreme court of the State of Colorado, I deem it entirely proper to state certain facts in connection with the case which will at least militate against 